\title{
Effect of tannin content in sorghum on digestive enzymes
}

\author{
Jeong-Suk Bae*, Hee-Sun Ko, Hong-Jib Choi, Ji-Yun Lee, Se-Jong Kim \\ Department Crops Breeding, Gyeongsangbuk-do Agricultural Research and Extension Services, Daegu 41404, Korea
}

\section{수수의 탄닌 함량이 소화효소에 미치는 영향}

\author{
배정숙*·고희선·최홍집 · 이지윤·김세종 \\ 경상북도농업기술원 작물육종과
}

\begin{abstract}
We evaluated the distribution pattem of tannin in 164 sorghum breeding lines and the inhibition rates of amylase, protease, and lipase in sorghum lines with different tannin concentrations. Tannin was existed in the testa of sorghum grain. The tannin content in whole grain of Nampungchal sorghum was $11.54 \mathrm{mg} / \mathrm{g}$, and that in grain (milling rate $73 \%$ ) and bran fractions was $4.57 \mathrm{mg} / \mathrm{g}$ and $28.71 \mathrm{mg} / \mathrm{g}$, respectively. The inhibition rate of a-amylase, a -glucosidase, and $\beta$-glucosidase in sorghum lines with tannin was higher than that in sorghum lines without tannin. The inhibition rate of a-glucosidase was greater than $97 \%$ in sorghum lines with tannin. The inhibition rate of protease ranged from $\mathbf{2 0} \%$ to $\mathbf{7 0} \%$ in the sorghum lines, showing no discemable trends in tannin content. Lipase inhibition was either very low or not observed and did not seem to correlate with tannin concentration.
\end{abstract}

Key words : sorghum, tannin, a-amylase, lipase, protease

\section{서 론}

수수(Sorghum bicolor)는 고온, 건조에 강한 작물로 밀, 옥수수, 벼, 보리에 이어 세계적인 주요작물로 널리 재배되 고 있다. 우리나라에서도 오곡밥에 빼놓을 수 없는 잡곡 중 하나로 돌떡, 수수부꾸미 등 다양한 전통음식에 이용되 어 오고 있다(1).

수수는 화곡류 식량작물 중에서 특이하게 탄닌을 함유하 고 있다. 탄닌은 분자량 500 3,000의 수용성 페놀성 물질로 구조 차이에 따라 가수분해형 탄닌(hydrolyzable tannins)과 축합형 탄닌(condensed tannins)으로 분류된다. 감, 녹차 등 고등식물에는 주로 축합형 탄닌이 분포하는 것으로 알려져 있다(2). 식물성 탄닌은 단백질과 잘 결합하는 성질을 가지 고 있으며 혀의 점막단백질과 결합하면 떫은 맛을 내고,

*Corresponding author. E-mail : jsbae24@korea.kr Phone : 82-53-320-0287, Fax : 82-53-320-0294

Received 16 August 2016; Revised 28 September 2016; Accepted 16 October 2016.

Copyright (c) The Korean Society of Food Preservation. All rights reserved.
산화, 환원 반응의 기질로 작용하여 식품의 갈변현상을 일 으키기도 한다.

최근 미국, 일본 등에서는 수수가 gluten free 곡물로 주목 받아 밀가루 대체재로써 소맥 알레르기인 글루텐 불내증, 셀리악병을 일으키지 않는 건강식품으로 각광 받으면서 수수빵, 수수맥주 등 수수를 이용하기 위한 다양한 식품 가공 기술을 연구 개발하고 있다(3). 또한 수수는 폴리페놀 과 탄닌 등의 항산화 성분을 매우 풍부하게 함유하고 있어 수수 추출물을 이용한 고지혈증, 고혈당증, 혈전 예방 등 성인병 예방에 도움이 되는 건강기능성 식재료로 부각되고 있으며(4), 특히 당뇨병 환자의 혈당 조절에 도움을 주는 것으로 보고되어 있다(5). 수수의 탄닌 성분은 항균, 항암, 항염증 효과, 미백, 다이어트 효과, 염색, 폐수처리에 대한 연구도 보고되고 있다(1,6-8). 이외에도 수수의 종류에 따라 탄닌 함량이 높은 경우에는 곰팡이 등의 미생물 또는 조류 및 해충에 대한 저항성은 높으나, 수수의 탄닌은 동물이나 인간에게 영양저해인자로 인식되어 이를 제거하려는 연구 와 분석법 개발도 보고되고 있다 $(9,10)$.

최근 기능성식품에 대한 관심이 높아지면서 수수를 비롯 한 국내 잡곡의 기능성에 대한 연구가 이루어지고 있으나 
(11), 재래종 수수 유전자원이나 품종에서의 탄닌 분포가 다양하지 못하여 탄닌을 이용한 식품 및 가공 이용성을 연구가 이루어지기 어렵고, 국내의 수수품종 육종이 초기 단계라 재배적인 농업형질 이외의 수수 탄닌에 대한 품종개 발에 이르지 못하고 있는 실정이다.

이에 본 연구는 수수 탄닌을 이용한 식품 및 가공 이용성 에 적합한 품종 개발을 위하여 수수 교배후대 계통들의 탄닌 함량을 분석하고, 이들 계통 중 탄닌 함량별 소화효소 들의 저해 반응을 조사하여 수수 탄닌의 다양한 용도 개발 을 위한 기본정보를 제공하고자 실시하였다.

\section{재료 및 방법}

\section{시료 및 전처리}

본 연구에 사용된 시료는 수수의 다양한 변이를 창출하 고자 재래종간 교배육성한 집단을 2014년 경상북도농업기 술원 포장에 재배하여 수확한 교배후대집단(F4 seed)의 164 계통들과 남풍찰수수의 조곡을 건조하여 사용하였다. 수수 의 종실 내 탄닌과 총폴리페놀 함량의 분포를 조사하기 위해 남풍찰수수의 도정 율 $(65 \%, 73 \%, 83 \%, 92 \%$, 조곡 $)$ 을 달리하여 탄닌 함량을 조사하였다. 탄닌 함량에 따른 소화 효소들의 반응을 조사하기 위해서는 남풍찰수수를 대조로 하여 164 계통 중 탄닌 함량별로 선발된 15 계통의 조곡을 대상으로 측정하였다. 시험에 사용된 모든 시료는 ball mill(MM400, Retsch GmbH, Haan, Germany)로 분쇄하여 사용하였다.

\section{탄닌과 총폴리페놀 함량}

수수의 탄닌 함량의 분석은 한국산업표준법(KS H ISO 9648:2009, 이하 KS법)(12)으로 측정하였다. 시료를 75\% dimethylformamide로 추출한 상등액을 사용하여 $\mathrm{NH}_{3}$ 용액 및 ammonium iron(III) citrate 용액으로 발색하여 흡광분석 기(SPECTRO Star Nano BMG Labtech, Ortenberg, Germany) 로 $525 \mathrm{~nm}$ 에서 흡광도를 측정하였다. 이에 대한 대조구는 구연산철 암모늄 용액을 넣지 않은 조건으로 반응시켜 측정 하였다. KS법을 이용하여 측정된 흡광도는 탄닌산(Sigma, Belgium)을 사용하여 농도별로 작성한 표준곡선에 기준하 여 환산하였다.

총폴리페놀 함량 분석은 Folin-Denis 방법(13)에 기준하 여 흡광분석기 $760 \mathrm{~nm}$ 에서 흡광도를 측정하였다. 측정된 흡광도는 탄닌산을 이용하여 농도별로 작성한 표준곡선에 기준하여 환산하였다

\section{소화효소 활성}

수수의 탄닌이 소화효소에 미치는 영향을 알아보고자, 각 분말 시료 $0.5 \mathrm{~g}$ 에 $80 \%$ methanol $10 \mathrm{~mL}$ 를 첨가하여 shaking incubator에서 1 시간 동안 진탕배양 $(150 \mathrm{rpm})$ 한 후 원심분리 $(3,500 \mathrm{rpm}, 10 \mathrm{~min})$ 하여 얻은 상등액을 이후의 분석실험에 사용하였다. 탄닌 함량별로 선발된 수수 15 계 통과 대조구로 남풍찰수수와 추청벼 현미를 이용하여 당질 가수분해효소(a-amylase, a-glucosidase, $\beta$-glucosidase)와 단백질 분해효소(protease) 및 지질 분해효소(lipase)의 저해 율을 조사하였다, 이들 소화효소의 저해율과 탄닌과의 연 관성을 검정하고자 탄닌 또는 페놀성 물질과 선택적으로 결합하는 물질인 polyvinylpyrrolidone(PVP)을 처리하여 탄 닌을 비롯한 페놀성 물질이 제거된 후의 저해율을 측정한 실험군과 비교하였다.

\section{$\mathrm{a}-\mathrm{Amylase}$ 활성}

QuantiChrom a-Amylase Assay Kit(Bioassay systems, USA)를 사용하여 a-amylase의 저해율을 조사하였다. 시료 $10 \mu \mathrm{L}$ 에 기질용액 $170 \mu \mathrm{L}$, 증류수 $10 \mu \mathrm{L}$, 효소용액(Sigma porcine pancreas a-amylase $0.1 \mathrm{mg} / \mathrm{mL}$ ) $10 \mu \mathrm{L}$ 를 혼합하여 $37^{\circ} \mathrm{C}$ 에서 5 분 동안 반응시키고 stop reagent $80 \mu \mathrm{L}$ 를 넣어 섞은 후 원심분리기(Micro17R, Hanil science industrial Co., Ltd., Inchun, Korea)에서 $14,000 \mathrm{rpm}$ 으로 5 분간 원심분리하 고 그 상등액을 취해서 $595 \mathrm{~nm}$ 에서 흡광도를 측정하였다. 대조구는 시료 대신 증류수를 넣어 반응시켰고, PVP에 의 한 효소활성의 회복율을 보기 위해서는 $2 \% \mathrm{PVP}$ 용액을 더 첨가한 반응액으로 측정하였다. 효소의 저해율(\%)은 대조구의 흡광도에 대한 시료의 흡광도의 백분율로 나타내 었다.

Inhibition activity $(\%)=[1-($ sample OD/control OD) $] \times 100$

$a-G l u c o s i d a s e$ 와 $\beta-G l u c o s i d a s e$ 활성

a-glucosidase에 대한 저해율은 QuantiChrom a-Glucosidase Assay Kit(Bioassay systems, CA, USA)를 사용하여 조사하 였다. 각 시료와 효소용액(Sigma a-glucosidase from Saccharomyces cerevisiae) 및 제조사의 working reagent를 혼합하여 $405 \mathrm{~nm}$ 에서 흡광도를 즉시 측정하였고 $(\mathrm{t} 0), 20$ 분 후 한번 더 측정하였다(t20). 각 시료의 저해율(\%)은 $\mathrm{t} 20$ 값

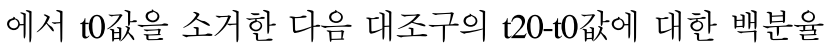
로 환산하였다. 또한 $\beta$-glucosidase의 저해율을 구하기 위해 서는 QuantiChrom $\beta$-glucosidase Assay Kit를 사용하였으 며, 효소용액(Sigma $\beta$-glucosidase from almonds)과 기질을 달리하여 앞서 기술한 a-glucosidase와 마찬가지의 방식으 로 측정하였다.

\section{Protease 활성}

Folin-Ciocalteu법(14)을 응용하여 수행하였다. 시료에 대 하여 효소용액(Sigma bovin pancreas protease), 인산 buffer $\left(\mathrm{pH}\right.$ 7.5) 및 기질용액(casein)을 혼합하여 $37^{\circ} \mathrm{C}$ 에서 반응한 
후 5\% tricholoroacetic acid 용액을 처리하였고, 원심분리 후 상등액을 phenol 시약으로 발색하여 $620 \mathrm{~nm}$ 에서 흡광도 를 측정하였다.

\section{Lipase 활성}

Bier의 비색법(15)을 응용하여 수행하였다. 각 시료에 lipase(Sigma lipase from porcine pancreas) 용액을 혼합하여 예열 후 기질용액(p-nitrophenol acetate)을 혼합하여 $37^{\circ} \mathrm{C}$ 에 서 반응시킨 다음 $400 \mathrm{~nm}$ 에서 흡광도를 측정하였다.

탄닌산 농도별 소화효소 활성 변화

수수의 소화효소의 활성 저해가 탄닌에 의한 영향인지 조사하기 위해 탄닌산 용액의 농도 $(0,5,10,50$, 및 100 $\mu \mathrm{M})$ 를 달리하여 5 가지 효소의 활성 변화를 검토하였다.

\section{통계분석}

실험결과는 SAS program(version 9.2, SAS Inst., Inc., Gray, NC, USA)을 이용하여 분산분석(ANOVA)을 실시하 여 유의성이 있는 처리에 대하여 Duncan's multiple range test로 계통간의 유의적 차이를 분석하였다 $(\mathrm{p}<0.05)$.

\section{결과 및 고찰}

\section{탄닌과 총폴리페놀 분석}

수수의 종실 내 탄닌과 총폴리페놀의 분포와 함량을 조 사하기 위해 남풍찰수수를 도정하여 무게에 따른 도정율별 (Fig. 1)로 종실과 겨를 나누어 각각의 추출물의 탄닌 함량 과 총폴리페놀 함량을 조사하였다. 종실색은 도정을 많이 해서 도정율이 낮아질수록 밝아졌으며 겨는 $73 \%$ 도정 율에 서 가장 진하게 나타나, 수수 색소는 종자의 과피와 종피층 에 존재함을 확인할 수 있었다.

남풍찰수수의 도정율에 따른 탄닌과 총폴리페놀 함량
(Table 1)은 도정을 하지 않은 조곡에서 각각 $11.54 \mathrm{mg} / \mathrm{g}$, $14.73 \mathrm{mg} / \mathrm{g}$ 이었고, $65 \%$ 도정한 종실에서는 각각 $2.06 \mathrm{mg} / \mathrm{g}$, $5.32 \mathrm{mg} / \mathrm{g}$ 으로 적었다. 한편 조곡을 도정한 겨의 탄닌과 총폴리페놀 함량은 조곡에 비해 각각 2 배 이상, 1.5 배 이상 높았으며, 특히 $73 \%$ 도정한 겨의 탄닌과 총폴리페놀 함량 은 $28.71 \mathrm{mg} / \mathrm{g}, 27.58 \mathrm{mg} / \mathrm{g}$ 으로 가장 많았다가 $65 \%$ 도정한 겨에서는 $26.38 \mathrm{mg} / \mathrm{g}, 25.39 \mathrm{mg} / \mathrm{g}$ 으로 적어졌다. 이는 Earp 과 Rooney (16)의 총폴리페놀과 탄닌의 분포가 과피와 배유 사이의 종피층 색소에 분포한다는 보고와 일치하였다. 또 한 Lee와 Lee의 보고(13) 중 다른 식물성 식품들과 비교해서 수수와 모과에서 축합형 탄닌량이 총폴리페놀량보다 높게 나타나는 특성을 보이는 것과 비슷하였다. Mabelebele 등 (17)은 수수의 총폴리페놀과 축합형 탄닌 및 항산화능 (antioxidant activity)이 높은 상관관계를 있다고 하였다. 이 는 종실의 탄닌 성분 이용 및 보다 많은 탄닌을 함유한 수수 겨의 바이오매스 자원을 이용한 항산화 물질 등 기능 성 물질 개발로의 가능성을 보여 주었다.

Table 1. Tannin and total polyphenol contents in 'Nampungchal' sorghum extract according to the seed milling ratio

\begin{tabular}{cccc}
\hline \multicolumn{2}{c}{ Milling ratio } & $\begin{array}{c}\text { Tannin } \\
(\mathrm{mg} / \mathrm{g})\end{array}$ & $\begin{array}{c}\text { Total polyphenol } \\
(\mathrm{mg} / \mathrm{g})\end{array}$ \\
\hline $100 \%$ & Whole grain & $11.54 \pm 0.1^{\mathrm{e} 1)}$ & $14.73 \pm 0.63^{\mathrm{e}}$ \\
$92 \%$ & milled grain & $9.67 \pm 0.25^{\mathrm{f}}$ & $13.62 \pm 1.32^{\mathrm{f}}$ \\
& bran & $20.93 \pm 0.14^{\mathrm{d}}$ & $20.26 \pm 0.48^{\mathrm{d}}$ \\
$83 \%$ & milled grain & $9.04 \pm 0.74^{\mathrm{g}}$ & $13.03 \pm 0.44^{\mathrm{g}}$ \\
& bran & $23.25 \pm 0.64^{\mathrm{c}}$ & $22.51 \pm 0.60^{\mathrm{c}}$ \\
$73 \%$ & milled grain & $4.57 \pm 0.09^{\mathrm{h}}$ & $8.06 \pm 0.23^{\mathrm{h}}$ \\
& bran & $28.71 \pm 0.59^{\mathrm{a}}$ & $27.58 \pm 0.63^{\mathrm{a}}$ \\
$65 \%$ & milled grain & $2.06 \pm 0.04^{\mathrm{i}}$ & $5.32 \pm 0.66^{\mathrm{i}}$ \\
& bran & $26.38 \pm 1.19^{\mathrm{b}}$ & $25.39 \pm 1.11^{\mathrm{b}}$ \\
\hline
\end{tabular}

${ }^{1)}$ Means with different small letters in the same column are significantly $(\mathrm{p}<0.05)$ by Duncan's multiple range test.

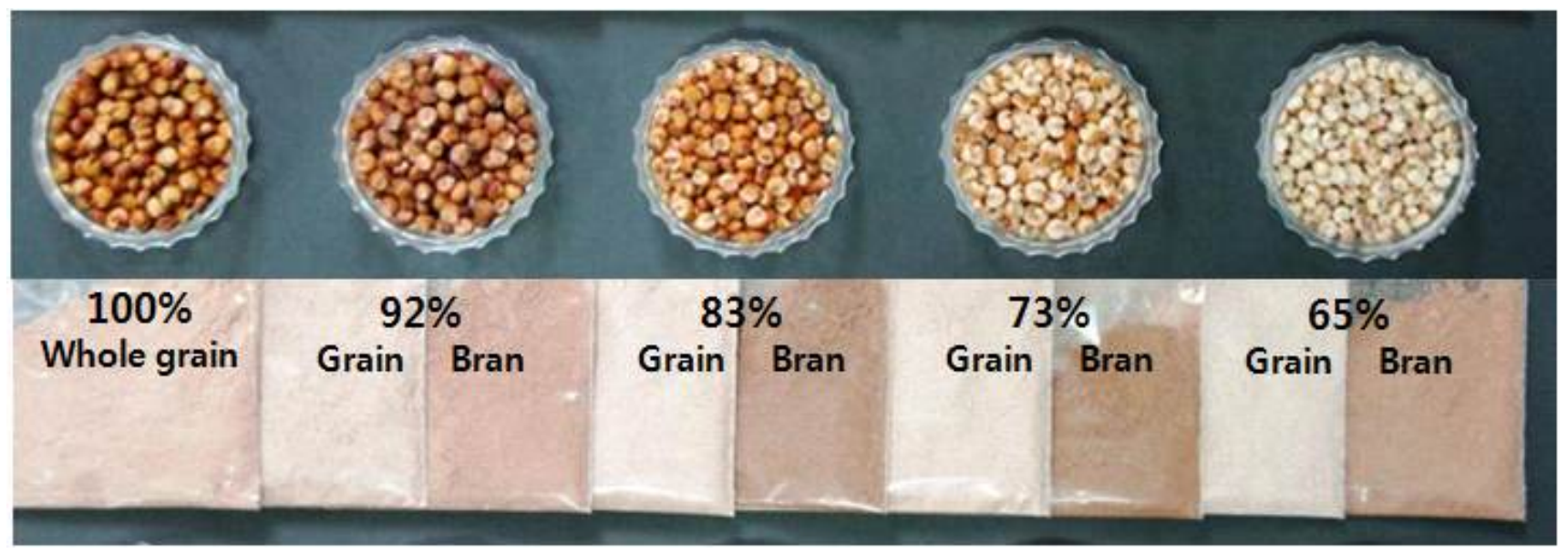

Fig. 1. Grain and powder color of grain and bran according to seed milling ratio of 'Nampungchal' sorghum. 
탄닌 함량의 다양성을 위해 육성한 교배후대집단(F4 seed)의 조곡 탄닌 함량을 분석한 결과(Fig. 2), 164계통의 탄닌 함량은 $5 \sim 10 \mathrm{mg} / \mathrm{g}$ 에서 가장 많은 계통들이 분포하는 정규분포를 나타내어 탄닌 형질은 관여하는 유전자수가 많은 양적형질임을 알 수 있었다. Maxson과 Rooney(18)의 5 종류의 탄닌분석법별 수수 종실의 탄닌 함량은 분석방법 에 따라 $0.0039 \% ~ 10.5 \%$ 차이가 있다고 보고하였으며, 표준 물질을 탄닌산으로 사용한 AOAC Folin-Denis법과 Snee Extraction plus Folin-Denis 분석방법에서 0.0039 1.65\% 범 위로 보고되어 본 연구의 교배후대 집단을 $\mathrm{KS}$ 법으로 분석 한 탄닌 함량 범위(0 1.77\%)와 비슷하였다.

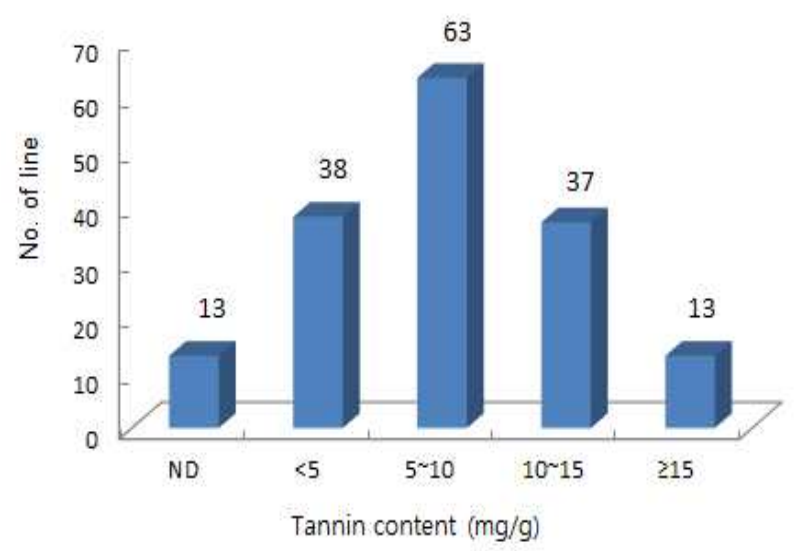

Fig. 2. Distribution of tannin contents in 164 sorghum lines.

\section{소화효소 활성 저해}

수수의 탄닌 함량이 소화효소에 미치는 영향을 알아보고 자, 교배후대집단 164 계통 중 탄닌 함량별로 선발된 수수 15 계통(Table 2)의 시료 추출물과 표준품종으로 남풍찰수 수와 대비로 추청벼 현미를 이용하여 당질 가수분해효소들 (a-amylase, a-glucosidase, $\beta$-glucosidase)의 저해율과 PVP 를 처리한 다음 당질 가수분해효소들의 저해율을 조사한 실험군과 비교하였다(Table 3).

당질 가수분해효소 중 a-amylase 저해율은 탄닌이 검출 되지 않은 SL 3계통과 SL 19계통에서 각각 $12.18 \%, 16.84 \%$ 로 낮았으나, 탄닌이 검출된 계통들에서는 $52.68 \%$ 84.94\% 로 높았다. 특히 혈당 저하와 관련 있는 효소로 알려진 a -glucosidase 저해율은 탄닌이 함유된 계통들에서 97.64 $99.91 \%$ 로 탄닌이 없는 계통들과 유의적인 차이를 보였다. 한편 대비로 이용된 현미(추청벼) 추출물의 경우에는 $a$ -glucosidase 저해가 나타나지 않았다. $\beta$-glucosidase 활성은 $10 ~ 30 \%$ 의 저해율을 보여 a-amylase와 a-glucosidase에 비해 낮게 나타났다. 탄닌이나 페놀성 물질을 결합하는 물질로 알려진 PVP를 처리한 경우 모든 탄닌 계통들에서 당질 가수분해효소들의 저해율이 낮아졌다. 특히 a-glucosidase 의 경우 남풍찰수수를 비롯한 4계통(SL 152, SL 94, SL
$135, \mathrm{SL} 36)$ 은 활성이 완전히 회복되어 탄닌이나 페놀성 물질이 소화에 영향을 미침을 알 수 있었으나, 탄닌 함량이 높은 7계통(SL 63, SL 17, SL85, SL 160, SL 81, SL 1, SL 70)의 a-glucosidase 활성이 회복되긴 했으나 $60 \%$ 이상의 저해율을 보여 탄닌 이외의 물질도 소화에 관여함을 알 수 있었다.

Table 2. Tannin content in 15 sorghum lines selected from 164 sorghum lines

\begin{tabular}{|c|c|c|}
\hline Source & Sorghum line & Tannin $(\mathrm{mg} / \mathrm{g})$ \\
\hline Control variety & Nampungchal & $11.54 \pm 0.19^{\mathrm{dl})}$ \\
\hline \multirow{2}{*}{$\begin{array}{l}\text { Non-tannin } \\
\text { lines }\end{array}$} & SL 3 & $\mathrm{ND}^{2)}$ \\
\hline & SL 19 & $\mathrm{ND}$ \\
\hline \multirow{13}{*}{$\begin{array}{l}\text { Tannin } \\
\text { lines }\end{array}$} & SL 152 & $3.51 \pm 0.15^{\mathrm{k}}$ \\
\hline & SL 119 & $4.39 \pm 0.45^{\mathrm{j}}$ \\
\hline & SL 94 & $6.56 \pm 0.09^{\mathrm{i}}$ \\
\hline & SL 140 & $6.75 \pm 0.15^{\mathrm{i}}$ \\
\hline & SL 135 & $8.04 \pm 0.45^{\mathrm{h}}$ \\
\hline & SL 36 & $8.47 \pm 0.15^{\mathrm{g}}$ \\
\hline & SL 63 & $9.14 \pm 0.55^{\mathrm{f}}$ \\
\hline & SL 17 & $9.14 \pm 0.30^{f}$ \\
\hline & SL 85 & $10.78 \pm 0.70^{\mathrm{e}}$ \\
\hline & SL 160 & $12.95 \pm 0.50^{\mathrm{c}}$ \\
\hline & SL 81 & $15.00 \pm 0.15^{b}$ \\
\hline & SL 1 & $15.93 \pm 0.45^{\mathrm{a}}$ \\
\hline & SL 70 & $15.97 \pm 0.09^{\mathrm{a}}$ \\
\hline
\end{tabular}

${ }^{1)}$ Means with different small letters in the same column are significantly $(\mathrm{p}<0.05)$ by Duncan's multiple range test.

${ }^{2)}$ Not detected.

위의 결과는 식물유래 물질 또는 식품에 있어서 탄닌의 존재가 소화효소 활성에 영향을 미친다고 한 보고(14)와 탄닌의 존재는 protein-tannin interaction에 의해서 소화 기 능을 잃게 만들어 동물의 소화율을 떨어뜨린다는 보고(19) 와 유사하다. Park 등은 황금찰수수 추출물을 생쥐 사료에 첨가하여 적절한 양의 복용이 글루코스 대사에 있어서 인슐 린 감수성의 향상 및 항당뇨 효과를 나타내었다고 보고하였 다(5). Juntheikki와 Ritta(20)는 $\beta$-glucosidase와 tannin의 복 합체가 효소활성에는 큰 영향을 주지는 않는다고 보고하였 다. 또한 $\beta$-glucosidase는 탄닌 저감화와 관련성 있는 효소 라는 보고(21)가 있어 비교적 덜 영향을 받는 것으로 생각되 었다.

남풍찰수수와 탄닌 함량별 수수 15 계통의 추출물을 대상 으로 단백질 분해효소(protease)와 지질 분해효소(lipase)의 저해율을 측정한 결과(Table 4), protease의 저해율은 탄닌 계통들에서 non-탄닌 계통들에 비해 전반적으로 높게 나타 났으나, 수수의 탄닌 함량과는 밀접한 관계가 없었다. 이는 
Table 3. Inhibition rates of starch hydrolyzing enzymes in sorghum lines different tannin concentration

\begin{tabular}{|c|c|c|c|c|c|c|c|}
\hline \multirow{3}{*}{\multicolumn{2}{|c|}{ Sorghum lines }} & \multicolumn{6}{|c|}{ Inhibition rate $(\%)$} \\
\hline & & \multicolumn{2}{|c|}{ a-amylase } & \multicolumn{2}{|c|}{ a-glucosidase } & \multicolumn{2}{|c|}{$\beta$-glucosidase } \\
\hline & & $-\mathrm{PVP}^{1)}$ & $+\mathrm{PVP}^{2)}$ & -PVP & $+\mathrm{PVP}$ & -PVP & $+\mathrm{PVP}$ \\
\hline \multirow{2}{*}{ Control } & $\begin{array}{l}\text { Sorghum var. } \\
\text { (Nampungchal) }\end{array}$ & $72.76^{\mathrm{h} 3)}$ & $4.47^{\mathrm{k}}$ & $99.87^{\mathrm{a}}$ & 4) & $36.87^{\mathrm{b}}$ & $25.14^{\mathrm{ab}}$ \\
\hline & $\begin{array}{c}\text { Rice } \\
\text { (Saechucheong) }\end{array}$ & $5.22^{\mathrm{m}}$ & - & - & - & $5.41^{\mathrm{g}}$ & $4.23^{\mathrm{k}}$ \\
\hline \multirow{2}{*}{ Non-tannin lines } & SL 3 & $12.18^{1}$ & $12.54^{\mathrm{f}}$ & $57.64^{b}$ & $8.74^{\mathrm{f}}$ & $12.91^{\mathrm{f}}$ & $11.17^{\mathrm{h}}$ \\
\hline & SL 19 & $16.84^{\mathrm{k}}$ & $19.71^{\mathrm{c}}$ & $35.70^{c}$ & $2.51^{\mathrm{g}}$ & $13.21^{\mathrm{f}}$ & $12.20^{\text {gh }}$ \\
\hline \multirow{13}{*}{ Tannin lines } & SL 152 & $52.68^{j}$ & $6.45^{\mathrm{i}}$ & $97.64^{a}$ & - & $13.86^{f}$ & $9.22^{\mathrm{i}}$ \\
\hline & SL 119 & $75.26^{\mathrm{g}}$ & $15.41^{\mathrm{e}}$ & $99.49^{\mathrm{a}}$ & $50.74^{\mathrm{e}}$ & $33.45^{\mathrm{c}}$ & $26.12^{\mathrm{a}}$ \\
\hline & SL 94 & $82.07^{\mathrm{bc}}$ & $8.96^{\mathrm{h}}$ & $99.43^{\mathrm{a}}$ & - & $26.71^{d}$ & $20.15^{\mathrm{c}}$ \\
\hline & SL 140 & $65.23^{\mathrm{i}}$ & $24.37^{\mathrm{b}}$ & $99.09^{\mathrm{a}}$ & $65.04^{\text {cd }}$ & $26.83^{d}$ & $15.34^{\text {de }}$ \\
\hline & SL 135 & $79.92^{\mathrm{de}}$ & $6.45^{\mathrm{ij}}$ & $99.91^{\mathrm{a}}$ & - & $23.43^{\mathrm{e}}$ & $13.56^{\mathrm{fg}}$ \\
\hline & SL 36 & $82.43^{\mathrm{b}}$ & $13.97^{\mathrm{f}}$ & $99.34^{\mathrm{a}}$ & - & $26.98^{d}$ & $16.61^{d}$ \\
\hline & SL 63 & $75.26^{\mathrm{g}}$ & $20.43^{\mathrm{c}}$ & $99.86^{\mathrm{a}}$ & $74.30^{\mathrm{b}}$ & $21.99^{\mathrm{e}}$ & $14.80^{\text {ef }}$ \\
\hline & SL 17 & $72.40^{\mathrm{h}}$ & $6.09^{j}$ & $99.34^{\mathrm{a}}$ & $67.29^{c}$ & $31.89^{\mathrm{c}}$ & $24.11^{b}$ \\
\hline & SL 85 & $81.00^{\text {cd }}$ & $9.67^{\mathrm{g}}$ & $99.49^{\mathrm{a}}$ & $60.80^{\mathrm{d}}$ & $26.83^{\mathrm{d}}$ & $15.63^{\mathrm{de}}$ \\
\hline & SL 160 & $79.57^{\mathrm{e}}$ & $16.12^{\mathrm{d}}$ & $99.57^{\mathrm{a}}$ & $78.12^{\mathrm{b}}$ & $39.54^{\mathrm{a}}$ & $24.11^{b}$ \\
\hline & SL 81 & $79.57^{\mathrm{e}}$ & $4.65^{\mathrm{k}}$ & $99.32^{\mathrm{a}}$ & $74.76^{b}$ & $22.02^{\mathrm{e}}$ & $7.80^{\mathrm{j}}$ \\
\hline & SL 1 & $77.77^{\mathrm{f}}$ & $27.24^{\mathrm{a}}$ & $99.37^{\mathrm{a}}$ & $84.96^{\mathrm{a}}$ & $28.31^{d}$ & $4.88^{\mathrm{k}}$ \\
\hline & SL 70 & $84.94^{\mathrm{a}}$ & $7.88^{h}$ & $99.52^{\mathrm{a}}$ & $77.01^{b}$ & $36.14^{b}$ & $19.18^{\mathrm{c}}$ \\
\hline
\end{tabular}

1)-PVP, No polyvinylpyrrolidone pretreatment.

${ }^{2)}+$ PVP, $2 \%$ polyvinylpyrrolidone pretreatment.

${ }^{33}$ Means with different small letters in the same column are significantly $(\mathrm{p}<0.05)$ by Duncan's multiple range test.

4)-, No inhibition.

각각 계통별 탄닌의 구조적 차이 등 다른 성분들의 특성에 의한 것이라는 보고 $(14,22)$ 가 있다.

Lipase 저해율은 $20 \%$ 이하로 저해가 일어나지 않거나 매우 낮아 수수 계통들간의 lipase 저해율의 유의성이 없었 다. 대비로 이용된 현미(추청벼) 추출물의 경우에는 protease 와 lipase에 대한 저해율이 매우 낮았다.

Lipase의 경우 탄닌류의 저해가 나타난다는 보고 $(23,24)$ 와 나타나지 않는다는 보고 $(14,25)$ 가 있었다. Lee와 Lee(13, 14)는 중합도가 낮은 축합형 탄닌을 함유하는 식물성 식품 에 수수와 모과를 포함하였고, 이 중 모과 시료가 a-amylase 와 protease 활성을 저해하고, lipase 활성은 증가시켰고, 모 과 시료에 PVP를 적용 시 a-amylase 및 protease에 대한 활성이 회복되었으나 lipase 활성에는 영향을 주지 않았다 고 보고하였다. 또한 페놀성 물질의 소화효소의 저해작용 은 경쟁적 저해가 아닌 무경쟁 저해 또는 비경쟁 저해에 의한 것으로 추측된다고 관련 실험을 통해 밝혔다(14). Al-Mamary 등(23)은 수수를 사료로 먹인 동물의 소장 상부 에서 채취한 소화물에서 a-amylase, trypsin 및 lipase의 활성 이 저해되었고, a-amylase에 대한 저해성이 가장 크고 trypsin, lipase 순으로 영향을 주는 것으로 보고하였다. 수수 계통들 중에 탄닌 함량이 높은 SL 1 과 SL 70 의 경우 당질 가수분해효소들과 지질 분해효소의 저해율은 높고 단백질 분해효소의 저해율은 낮아, 이들을 계통들을 대상으로 항비만이나 항당뇨에 대한 추가적인 연구가 필요 할 것으로 생각된다.

\section{탄닌산 농도별 소화효소 활성 변화}

수수의 각 소화효소에 대한 저해성이 탄닌에 의한 영향 인지를 알아보기 위해 탄닌산(tannic acid) 용액의 농도(0, $5,10,50$, 및 $100 \mu \mathrm{M}$ )를 달리하여 5 가지 소화효소에 미치는 영향을 조사하였다(Fig. 3). 탄닌산 농도가 높아짐에 따라 당질가수분해효소인 a-amylase, a-glucosidase 및 $\beta$ -glucosidase의 활성는 감소하였으며, 특히 a-glucosidase가 $5 \mu \mathrm{M}$ 의 낮은 탄닌산 농도에서도 매우 낮은 활성을 보였고, $50 \mu \mathrm{M}$ 이상 적용 시에는 완전히 실활되었다. 그리고 탄닌산 에 PVP를 첨가 시에는 $100 \%$ 이상의 활성 회복을 보여 a -glucosidase 활성은 특이적으로 탄닌산의 영향을 크게 받는 것으로 나타났다. $a$-amylase의 경우 비교적 미량의 탄닌산 


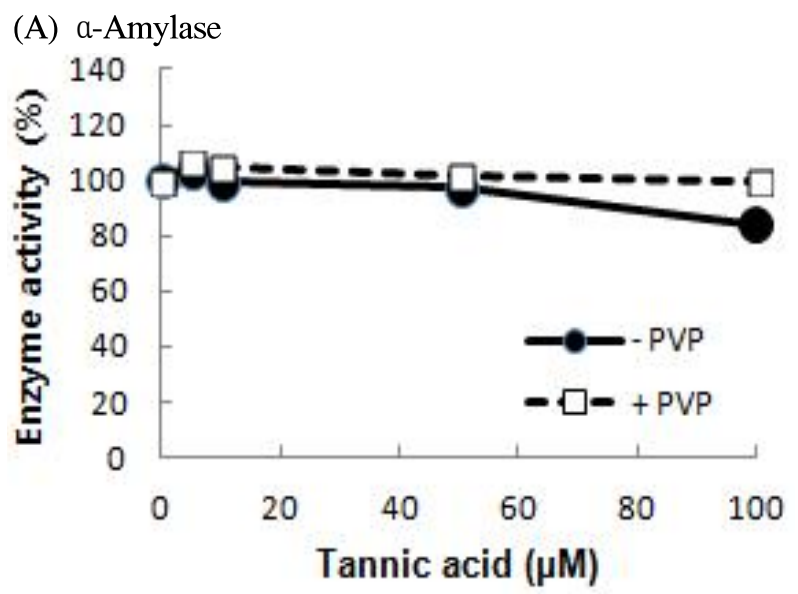

(B) a-Glucosidase

(C) B-Glucosidase
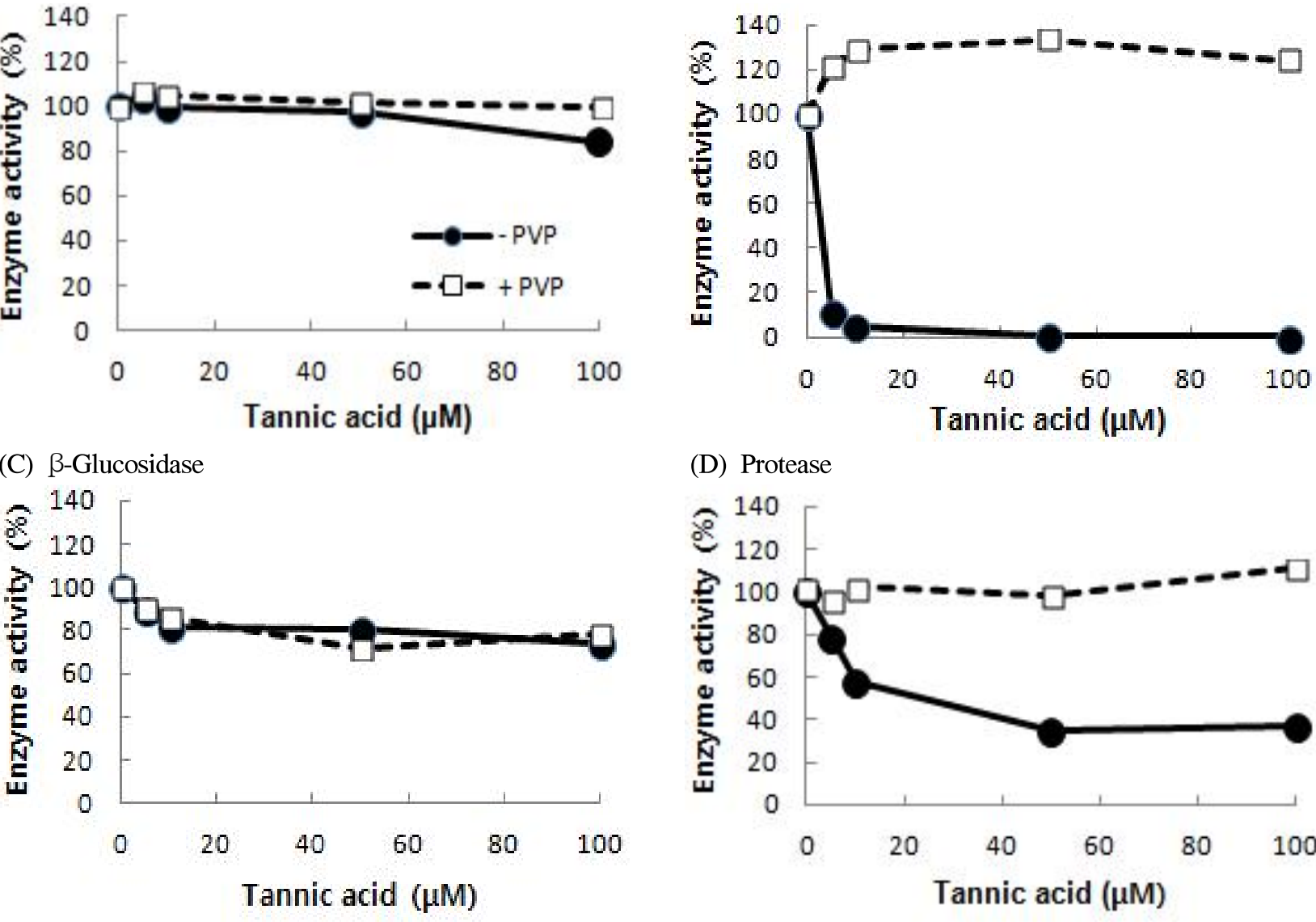

(D) Protease

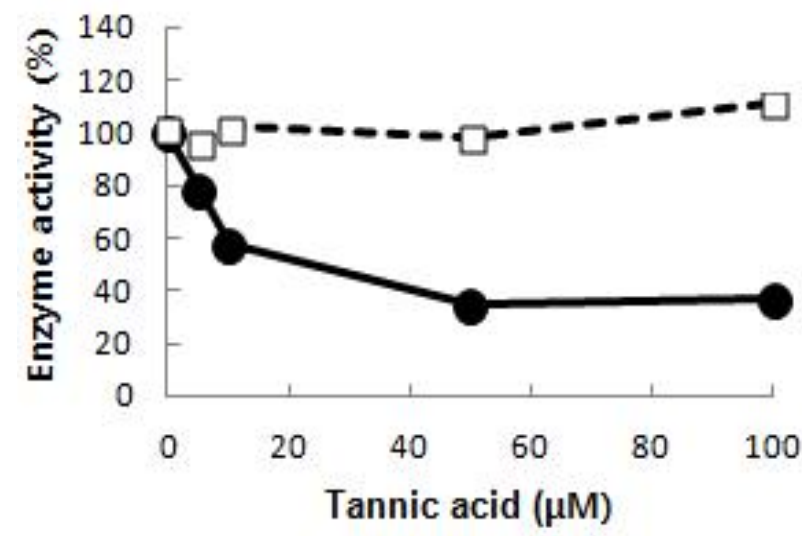

(E) Lipase

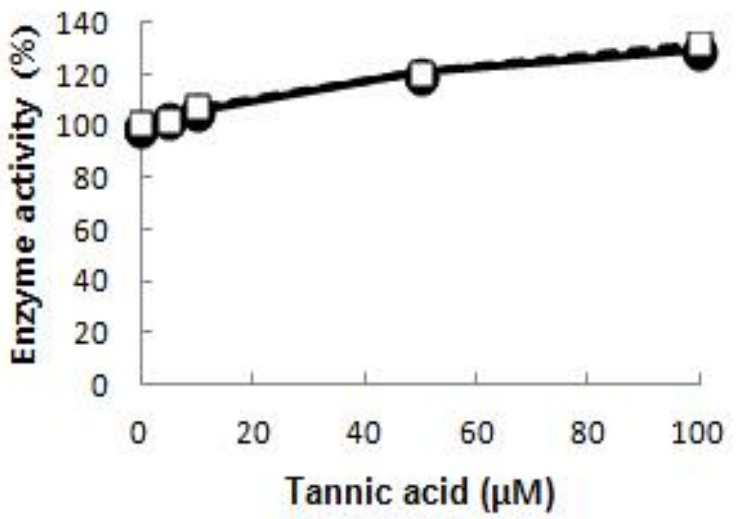

Fig. 3. Effect of different tannic acid concentrations on the main digestive enzymes.

- - -PVP, No polyvinylpyrrolidone pretreatment.

, +PVP, $2 \%$ polyvinylpyrrolidone pretreatment.

농도에 의한 저해율은 농도 증가에 따라 서서히 활성이 저해되는 양상을 보였다. B-glucosidase의 경우에는 $a$ -glucosidase와 달리 큰 저해가 일어나지 않고 완만한 저해 곡선을 보였으며 $100 \mu \mathrm{M}$ 농도 적용 시까지에도 $70 \%$ 대의 활성을 유지하였다. Protease의 경우에는 저농도에서부터 높은 저해를 보이기 시작하여 $50 \mu \mathrm{M}$ 이상의 농도 적용 시 $30 \%$ 대의 잔존 활성만을 유지하였으며, PVP 첨가로
96 111\%의 활성 회복율을 보였다. Lipase 활성은 탄닌산 농도 따른 활성의 변화가 크지 않았다. 수수 추출물의 경우 에는 수수 내의 탄닌 뿐만 아니라 여러 종류의 물질이 소화 효소를 저해하는데 함께 영향을 미치는 것으로 알려졌으나 (26), 본 연구결과에서는 탄닌산이 소화효소에 특히 $\mathrm{a}$ -glucosidase의 저해에 관여했음을 보였다. 이는 향후 항당 뇨와 항비만을 목적으로 하는 수수품종 육성에 필요한 정보 
라고 하겠다.

Table 4. Inhibition rates of protease and lipase in sorghum lines of different tannin concentration

\begin{tabular}{|c|c|c|c|c|c|}
\hline \multirow{3}{*}{\multicolumn{2}{|c|}{ Sorghum lines }} & \multicolumn{4}{|c|}{ Inhibition rate $(\%)$} \\
\hline & & \multicolumn{2}{|c|}{ Protease } & \multicolumn{2}{|c|}{ Lipase } \\
\hline & & $-\mathrm{PVP}^{1)}$ & $+\mathrm{PVP}^{2)}$ & $-P V P$ & $+\mathrm{PVP}$ \\
\hline \multirow{2}{*}{ Control } & $\begin{array}{l}\text { Sorghum var. } \\
\text { (Nampungchal) }\end{array}$ & $51.94^{\mathrm{e}(3)}$ & -4) & - & $0.43^{\mathrm{i}}$ \\
\hline & $\begin{array}{c}\text { Rice } \\
\text { (Saechucheong) }\end{array}$ & $11.64^{\mathrm{i}}$ & $49.55^{\mathrm{a}}$ & 5.42 & $5.97^{\mathrm{fg}}$ \\
\hline \multirow{2}{*}{$\begin{array}{c}\text { Non-tannin } \\
\text { lines }\end{array}$} & SL 3 & $23.13^{\mathrm{h}}$ & $35.22^{b}$ & 11.82 & $14.75^{\mathrm{cd}}$ \\
\hline & SL 19 & $24.48^{\mathrm{h}}$ & $38.36^{\mathrm{b}}$ & 17.57 & $12.91^{\mathrm{cd}}$ \\
\hline \multirow{13}{*}{$\begin{array}{l}\text { Tannin } \\
\text { lines }\end{array}$} & SL 152 & $60.74^{\text {cd }}$ & $24.33^{\mathrm{e}}$ & 5.21 & $13.34^{\text {cd }}$ \\
\hline & SL 119 & $70.90^{\mathrm{ab}}$ & $34.03^{b c}$ & - & $5.10^{\mathrm{fg}}$ \\
\hline & SL 94 & $73.28^{\mathrm{a}}$ & $29.55^{\text {cd }}$ & 19.63 & $22.78^{b}$ \\
\hline & SL 140 & $47.61^{\mathrm{f}}$ & $15.52^{\mathrm{gh}}$ & 4.77 & $16.27^{\mathrm{c}}$ \\
\hline & SL 135 & $64.18^{\text {bcd }}$ & $18.36^{\mathrm{fg}}$ & - & $16.70^{c}$ \\
\hline & SL 36 & $70.15^{\mathrm{ab}}$ & $11.04^{\mathrm{hi}}$ & 5.10 & $16.16^{\mathrm{c}}$ \\
\hline & SL 63 & $56.57^{\mathrm{de}}$ & $17.31^{\mathrm{g}}$ & 0.43 & $7.59^{\mathrm{ef}}$ \\
\hline & SL 17 & $60.00^{\mathrm{cd}}$ & $33.88^{\mathrm{bc}}$ & - & $3.58^{\mathrm{fgh}}$ \\
\hline & SL 85 & $40.30^{g}$ & $24.93^{\text {de }}$ & 15.62 & $31.45^{\mathrm{a}}$ \\
\hline & SL 160 & $56.42^{\mathrm{de}}$ & $11.64^{\mathrm{hi}}$ & 19.63 & $10.63^{\mathrm{de}}$ \\
\hline & SL 81 & $51.34^{\mathrm{eff}}$ & $8.06^{\mathrm{i}}$ & - & $4.99^{\mathrm{fg}}$ \\
\hline & SL 1 & $28.36^{\mathrm{h}}$ & - & 16.16 & $26.25^{b}$ \\
\hline & SL 70 & $65.67^{\mathrm{abc}}$ & $22.84^{\mathrm{ef}}$ & - & $2.82^{\text {gh }}$ \\
\hline
\end{tabular}

${ }^{1)}$-PVP, No polyvinylpyrrolidone pretreatment.

${ }^{2)}+$ PVP, $2 \%$ polyvinylpyrrolidone pretreatment.

${ }^{33}$ Means with different small letters in the same column are significantly $(\mathrm{p}<0.05)$

by Duncan's multiple range test.

4), No inhibition.

\section{요 약}

본 연구는 수수 계통들의 탄닌 함량별 소화효소 저해율 을 조사하여 향후 수수 품종육성과 수수의 이용성 향상을 위하여 실시하였다.

남풍찰수수의 탄닌의 분포를 조사한 결과, 과피와 배유 사이의 종피층에 탄닌이 분포함을 알 수 있었다. 도정을 하지 않은 조곡에서 탄닌 함량은 $11.54 \mathrm{mg} / \mathrm{g}$ 이었고, $73 \%$ 도정한 종실과 겨에서 각각 $4.57 \mathrm{mg} / \mathrm{g}$ 과 $28.71 \mathrm{mg} / \mathrm{g}$ 으로 가장 높게 나타났다가 $65 \%$ 도정한 종실과 겨에서 $2.06 \mathrm{mg} / \mathrm{g}$ 과 $26.38 \mathrm{mg} / \mathrm{g}$ 으로 줄었다.

수수 추출물 탄닌 함량별로 15 계통을 대상으로 소화효소 반응을 조사한 결과, 탄닌이 함유된 계통들에서 탄닌이 없 는 계통들에 비해 당질가수분해 효소인 a-amylase, $a$ -glucosidase, $\beta$-glucosidase 저해율이 높게 나타났다. 특히 a-glucosidase의 저해율은 모든 탄닌 계통에서 $97 \%$ 이상으 로 다른 소화효소들에 비해 매우 특이적으로 높은 저해율을 보였다.

Protease의 저해율은 탄닌 계통들에서 non-탄닌 계통들 에 비해 전반적으로 높게 나타났다. Lipase 저해율은 $20 \%$ 이하로 저해가 일어나지 않거나 매우 낮아 수수 계통들간의 lipase 저해율의 유의성이 없었다.

\section{감사의 글}

본 연구는 농촌진흥청 아젠다 사업(과제번호. PJ010504052016) 의 지원에 의해 수행되었다.

\section{References}

1. Kim JI, Jung TW, Ko JY, Song SB, Woo KS (2011) The versatile sorghum. RDA Interrobang, 109, 1-16

2. Kim IS (2003) Patterns of tannin accumulation in leaves of C-4 Euphorbia maculata. Korean J Electron Microscopy, 33, 233-241

3. Kim HY, Seo HI, Ko JY, Song SB, Kim JI, Lee JS, Jung TW, Kim KY, Kwak DY, Oh IS, Kim CS, Jeong HS, Woo KW (2012) Physicochemical characteristics of the muffin added glutinous and non-glutinous sorghum (Sorghum bicolor L. Moench) powder. Korean J Food Nutr, 25, 490-498

4. Mitsuru G, Kobayashi M, Suda I, Oki T, Gotoh K, Katsura M, Matsuoka H (2005) Varietal difference in proanthocyanidin content and radical-scavenging activity of sorghum grain. Kyushu agricultural research, 67, 104

5. Park JH, Lee SH, Chung IM, Park Y (2012) Sorghum extract exerts an anti-diabetic effect by improving insulin sensitivity via PPAR- $\gamma$ in mice fed a high-fat diet. Nutr Res Pract, 6, 322-327

6. Sa YJ, Kim JS, Kim MO, Jeong HJ, Yu CY, Park DS, Kim MJ (2010) Comparative study of electron donating ability, reducing power, antimicrobial activity and inhibition of a-glucosidase by Sorghum bicolor extracts. Korean J Food Sci Technol, 42, 598-604

7. Yoo HJ (2004) Antibacterial activities and dye ability of the tannin treated silk and wool fabrics. Journal of science and culture, 1, 107-115

8. Cho YJ, Chun SS (2005) Effect of wastewater treatment with tannins from peel of astringent persimmon fruits. Korean J Food Preserv, 3, 299-304 
9. Van Hoven W (1984) Tannin and digestibility in greater kudu. Can J Anim Sci, 64, 177-178

10. Schofield P, Mbugua DM, Pell AN (2001) Analysis of condensed tannins: a review. Anim Feed Sci Technol, 91, 21-40

11. Park DH, Lee ST, Jun DY, Lee Jy, Woo MH, Kim KY, Ko JY, Woo Ks, Jung TW, Kwak Dy, Nam MH, Kim YH (2014) Comparative evalution of antioxidant activities of ethanol extracts and their solvent fractions obtained from selected miscellaneous cereal grains. Journal of life science, 24, 26-38

12. Korean standard association (2009) SorghumDetermination of tannin content. KS H ISO 9648, 1-5

13. Lee JH, Lee SR (1994) Analysis of phenolic substances content in Korean plant foods. Korean J Food Sci Technol, 26, 310-316

14. Lee JH, Lee SR (1994) Some physiological activity of phenolic substances in plant foods. Korean J Food Sci Technol, 26, 317-323

15. Bier M (1955) Lipases. Methods Enzymol, 1, 627-642

16. Earp CF, Rooney LW (1982) Scanning electron microscopy of the pericarp and testa of several sorghum varieties. Food Struct 1, 125-134

17. Mabelebele M, Siwela M, Gous RM, Iji PA (2015) Chemical composition and nutritive value of South African sorghum varieties as feed for broiler chickens.

S Afr J Anim Sci, 45, 206-213

18. Maxson ED, Rooney LW (1972) Evaluation of methods for tannin analysis in sorghum grain. Cereal Chem, 49, 719-728
19. Reed JD (1995) Nutritional toxicology of tannins and related polyhenols in forage legumes. J Anim Sci, 73, 1516-1528

20. Juntheikki, MR, Ritta JT (2000) Inhibition of glucosidase and esterase by tannins from Betula, Salix, and Pinus species. J Chem Ecol, 26, 1151-1165

21. Shin HJ, Byun OH, Kim YJ, Bang BY, Park JM, Jeong YS, Bai DH (2015) Study of tannin reducing effect of aronia by yeast isolated from Jeotgal. Kor J Mycol, 43, 247-252

22. Carvalho E, Povoas MJ, Mateus N, de Feitas V (2006) Application of flow nephelometry to the analysis of the influence of carbohydrates on protein-tannin interaction. J Sci Food Agric, 86, 891-896

23. Al-Mamary M, Al-Habori M, Al-Aghbari A, Al-Obeidi A (2001) In vivo effects of dietary sorghum tannins on rabbit digestive enzymes and mineral absorption. Nutr Res, 21, 1393-1401

24. Karamac M, Amarowicz R (1996) Inhibition of pancreatic lipase by phenolic acid. Z Naturforsch C, 51, 903-905

25. Nwosu F, Morris J, Lund VA, Stewart D, Ross HA, McDougall GJ (2011) Anti-proliferative and potential anti-diabetic effects of phenolic-rich extracts from edible marine algae. 126, 1006-1012

26. Goncalves R, Mateus N, de Freitas V (2011) Inhibition of a-amylase activity by condensed tannins. Food Chem, $125,665-672$ 